University of Nebraska - Lincoln

DigitalCommons@University of Nebraska - Lincoln

USDA National Wildlife Research Center - Staff Publications
U.S. Department of Agriculture: Animal and Plant Health Inspection Service

2010

\title{
Polyurea Elastomer Protects Utility Pole Crossarms From Damage by Pileated Woodpeckers
}

\author{
Shelagh Tupper \\ USDA-APHIS-Wildlife Services \\ William Andelt \\ Colorado State University, Fort Collins, Department of Fish, Wildlife, and Conservation Biology \\ John Cummings \\ USDA-APHIS-Wildlife Services \\ Charles Weisner \\ Brooks Manufacturing Company \\ Richard Harness \\ EDM International, Incorporated
}

Follow this and additional works at: https://digitalcommons.unl.edu/icwdm_usdanwrc

Part of the Environmental Sciences Commons

Tupper, Shelagh; Andelt, William; Cummings, John; Weisner, Charles; and Harness, Richard, "Polyurea Elastomer Protects Utility Pole Crossarms From Damage by Pileated Woodpeckers" (2010). USDA National Wildlife Research Center - Staff Publications. 973.

https://digitalcommons.unl.edu/icwdm_usdanwrc/973

This Article is brought to you for free and open access by the U.S. Department of Agriculture: Animal and Plant Health Inspection Service at DigitalCommons@University of Nebraska - Lincoln. It has been accepted for inclusion in USDA National Wildlife Research Center - Staff Publications by an authorized administrator of DigitalCommons@University of Nebraska - Lincoln. 


\title{
Polyurea Elastomer Protects Utility Pole Crossarms From Damage by Pileated Woodpeckers
}

\author{
SHELAGH K. TUPPER, ${ }^{1}$ United States Department of Agriculture, Animal and Plant Health Inspection Service, Wildlife Services, National Wildlife \\ Research Center, 4101 LaPorte Avenue, Fort Collins, CO 80521-2154, USA \\ WILLIAM F. ANDELT, Department of Fish, Wildife, and Conservation Biology, Colorado State University, Fort Collins, CO 80523 , USA \\ JOHN L. CUMMINGS, United States Department of Agriculture, Animal and Plant Health Inspection Service, Wildlife Services, National Wildife \\ Research Center, 4101 LaPorte Avenue, Fort Collins, CO 80521-2154, USA \\ CHARLES WEISNER, Brooks Manufacturing Company, 2120 Pacific Street, Bellingham, WA 98229, USA \\ RICHARD E. HARNESS, EDM International, Incorporated, 4001 Automation Way, Fort Collins, CO 80521, USA

\begin{abstract}
Woodpeckers cause severe damage to utility poles and crossarms, resulting in substantial economic losses to utility companies. We evaluated effectiveness of a polyurea elastomer coating material for reducing damage by captive pileated woodpeckers (Dryocopus pileatus) to utility pole crossarms. Because woodpeckers inflicted essentially no damage to the fully coated crossarms, we infer that the coating material holds substantial promise for protecting utility pole crossarms. Additional research should be conducted to evaluate the coating under field conditions.
\end{abstract}

KEY WORDS barrier, coating, Dryocopus pileatus, utility industry, wildlife damage management, woodpecker.

Woodpeckers cause millions of dollars of damage to utility pole structures around the world. As early as 1910, McAtee (1911) noted woodpecker damage to telephone poles, telegraph poles, fence posts, and buildings. Turcek (1960) reported damage by woodpeckers across Europe and Asia, and Dennis (1964) discussed renewed interest in damage to utility poles in the United States. More recently, Salmon River Electric Cooperative (ID) identified 100 poles with woodpecker damage costing $\$ 385,000$ in repair and replacement (Abbey et al. 2000). Guadalupe Valley Electric Cooperative (TX) spent $\$ 193,000$ annually on woodpecker damage (Abbey et al. 2000). Bevanger (1997) reported an average annual cost of $\$ 500,000$ due to activities of the black woodpecker (Dryocopus martius) and green woodpecker (Picus viridis) in Norway.

In general, the Melanerpes, Colaptes, Dryocopus, and Picoides genera within the family Picidae are primarily responsible for damage to utility structures. The most destructive species include the ladder-backed woodpecker (Picoides scalaris), golden-fronted woodpecker (Melanerpes aurifrons), red-headed woodpecker (Melanerpes erythrocephalus), acorn woodpecker (Melanerpes formicivorus), northern flicker (Colaptes auratus), gilded flicker (Colaptes chrysoides), and pileated woodpecker (Dryocopus pileatus; Dennis 1964). Ladder-backed, golden-fronted, and acorn woodpeckers cause damage to utility pole crossarms causing structural weakness. Pileated woodpeckers cause some of the most severe damage to poles, especially when excavating nesting cavities during February and March and roosting cavities during September through December (Jorgensen et al. 1957, Dennis 1964, Rumsey 1970).

\footnotetext{
${ }^{1}$ E-mail: Shelagh.K.Tupper@aphis.usda.gov
}

Damage to structures caused by woodpeckers presents a safety hazard to workers, may promote decay fostered by water entrapped in holes, necessitates premature replacement, and may lead to collapse under adverse conditions. For example, due to damage by woodpeckers, a Tampa Electric Company (FL) pole snapped and caused a cascading failure that resulted in $>100,000$ people losing power for more than an hour (Abbey et al. 2000). Woodpecker damage is not uniformly distributed within a transmission or distribution system but rather is localized depending on the species and number of woodpeckers and available foraging and nesting habitat (Stemmerman 1988).

Several techniques are available for alleviating woodpecker damage, such as exclusion, scare tactics, chemical repellents, and lethal removal; however, each of these techniques has limitations because of cost, logistics, effectiveness, or a combination of these factors (Abbey et al. 2000). Chemical repellents such as creosote, ammoniacal copper zinc arsenate, and methyl anthranilate were ineffective for reducing damage to poles by pileated woodpeckers (Rumsey 1970, Belant et al. 1997; D. Roberts, New York State Electric and Gas, personal communication). Some chemical pole treatments have shown positive results in cage testing but field testing has been stalled because of registration issues (Cummings et al. 2001).

Since the 1960s, no new products have been developed for successfully protecting wooden structures from woodpeckers. Most methods for alleviating damage by woodpeckers have been evaluated for utility poles; however, damage to crossarms of poles also occurs. Our objective was to evaluate effectiveness of a polyurea elastomer coating material being applied in a process developed by Brooks Manufacturing Company (Bellingham, WA) to eliminate or reduce damage to crossarms by woodpeckers. 


\section{METHODS}

We captured pileated woodpeckers during 10-19 April 2007 in the Rolla Ranger District of Mark Twain National Forest, Rolla, Missouri, USA $(n=6)$, and the Cass Ranger District of Ozark National Forest, Cass, Arkansas, USA ( $n$ =12). We captured woodpeckers using a mist net and taped pileated woodpecker call (York et al. 1998). We conducted research on pileated woodpeckers at the Outdoor Animal Research Facility, National Wildlife Research Center (NWRC), Fort Collins, Colorado, USA. At NWRC, pileated woodpeckers were housed separately in outdoor aviaries $(3.3 \times 3.3 \times 6.6 \mathrm{~m}, n=10$; and $2.6 \times 2.6 \times 5.3 \mathrm{~m}$, $n=8)$. We lined holding and test pens with nylon-mesh nets to prevent injuries to woodpeckers. Capture, care, and use of birds were approved by NWRC's Institutional Animal Care and Use Committee (NWRC study protocol QA1459) and Colorado State University's Animal Care and Use Committee (protocol number 07-074A-01).

We transported woodpeckers in individual holding cages $(50 \times 61 \times 50 \mathrm{~cm})$ to the NWRC Outdoor Animal Research Facility. Each cage had a wooden perch and we supplied each woodpecker with food and water ad libitum during transport. At the conclusion of testing, we returned pileated woodpeckers to capture locations.

Daily diet for woodpeckers consisted of $20 \mathrm{~g}$ of canine diet canned dog food (beef), $35 \mathrm{~g}$ of mealworms, and $50 \mathrm{~g}$ of mixed fruit (consisting of apples, oranges, bananas, and grapes; J. Phillips, Caldwell, Texas Zoo, personal communication, modified by J. E. Davis, Jr., NWRC). Each woodpecker had free access to food, water, and one untreated $30-\mathrm{cm}$-diameter by $1.2-\mathrm{m}$-high southern yellow pine (Pinus palustris) utility pole section.

Brooks Manufacturing Company supplied $243 \times 8.5 \times$ 11-cm Douglas fir (Pseudotsuga menziesii) crossarms that were completely coated and crossarms that were coated on the top surface and approximately $2.5 \mathrm{~cm}$ down from the top on each side. The coating material ranged from $1.0 \mathrm{~mm}$ to $2.54 \mathrm{~mm}$ thick and was a sprayed plural A and Bcomponent pure polyurea elastomer based on amineterminated polyether resins.

Prior to experimentation, we divided 18 test birds into 2 equally sized groups based on extent of damage to utility pole sections during quarantine (i.e., the 2 highest damagecausing birds assigned one to each group, the next 2 highest damage causing birds assigned one to each group, and so forth irrespective of sex) to reduce any bias due to incidence of damage. We then randomly assigned birds to either the fully coated or top-coated treatment groups. We conducted 2 experiments to evaluate effectiveness of the coating material to reduce woodpecker damage to utility pole crossarms.

We tested 9 birds on each coating application (fully coated: $n=7 \mathrm{M}, 2 \mathrm{~F}$; top-coated $n=8 \mathrm{M}, 1 \mathrm{~F}$ ) during 10 days of choice testing and 10 days of no-choice testing during 2 separate 20-day periods from 15 May 2007 to 24 June 2007. Initially we tested 10 birds ( $n=5$ fully coated; $n$ $=5$ top-coated), followed by 8 birds ( $n=4$ fully coated; $n$
$=4$ top-coated). We combined results from each test of the fully coated and top-coated crossarms. During choice testing, we offered a control crossarm and a treated crossarm, separated by $1.5 \mathrm{~m}$, to each woodpecker. We randomly chose initial locations of the treatment and control crossarms and switched them daily to account for any potential location bias. During no-choice testing, we removed the control crossarm leaving each bird with only the treated crossarm to which they had been previously exposed. We assessed extent of damage to crossarms daily between 0730 hours and 0830 hours. We recorded dried weight of removed wood chips, length and depth of damage, area of damage, and condition of the coating on the crossarm.

Woodpeckers did not damage fully coated crossarms in either choice or no-choice experiments. Due to this lack of homogeneity of variance of the fully coated crossarms, we used Fisher's exact test (PROC FREQ, SAS Institute Cary, $\mathrm{NC)}$ to compare the proportion of woodpeckers that damaged fully coated crossarms compared to control crossarms. We evaluated extent of damage to top-coated and top-coated control groups in our choice experiment with analysis of variance (PROC GLM), with days as repeated measurements. We used Fisher's exact test (PROC FREQ) to compare proportion of woodpeckers that damaged fully coated and top-coated crossarms in no-choice tests.

\section{RESULTS}

During choice testing, a lower proportion of woodpeckers inflicted damage, measured by grams of wood removed, to fully coated crossarms ( $n=0$ of 9 ) compared to controls for fully coated crossarms ( $n=7$ of $9 ; P<0.001$; Table 1 ). Woodpeckers removed less wood $(\mathrm{g})$ from top-coated crossarms compared to top-coated control crossarms $\left(F_{1,8}\right.$ $=13.54, P=0.006$; Table 1$)$. Damage to crossarms did not vary by bird $\left(F_{8,8}=0.97, P=0.518\right)$ or across days $\left(F_{9,72}=\right.$ $0.98, P=0.462)$. Of the 18 woodpeckers, 3 did not damage control crossarms, whereas the remaining birds removed $0.2-49.1 \mathrm{~g}$ of wood chips per day. Comparison of fully coated versus fully coated control and top-coated versus topcoated control treatments for the remaining variables (length, area, and depth) showed significant differences, similar to those above (Table 1).

During no-choice testing, a greater proportion of woodpeckers inflicted damage, measured by grams of wood removed, to top-coated crossarms ( $n=6$ of 9 ) than to fully coated crossarms $(n=0$ of 9$)$. Woodpeckers inflicted only minor damage, consisting of small nicks or scrapes $<2.0 \mathrm{~cm}$ long to the coating of both treatments and did not penetrate to the wood (Table 2). An average of $1.3 \mathrm{~g}(\mathrm{SE}=0.24 \mathrm{~g}$ ) of wood chips were removed daily below the coating material on top-coated crossarms.

\section{DISCUSSION}

The polyurea elastomer coating was effective in reducing damage by pileated woodpeckers to coated crossarms. Fully coated crossarms received no measurable damage. Other products have had limited success for protecting utility poles 
Table 1. Extent of damage by pileated woodpeckers to fully coated versus control crossarms and top-coated versus control crossarms during a 10 -day choice test at the National Wildlife Research Center, Fort Collins, Colorado, USA, 15 May 2007 to 14 June 2007.

\begin{tabular}{|c|c|c|c|c|c|c|c|c|c|c|c|c|}
\hline \multirow[b]{3}{*}{ Type of damage } & \multicolumn{5}{|c|}{ Fully coated } & \multicolumn{7}{|c|}{ Top-coated } \\
\hline & \multicolumn{2}{|c|}{ Treatment } & \multicolumn{2}{|c|}{ Control } & \multirow[b]{2}{*}{$P$} & \multicolumn{2}{|c|}{ Treatment } & \multicolumn{2}{|c|}{ Control } & \multirow[b]{2}{*}{ df } & \multirow[b]{2}{*}{$F$} & \multirow[b]{2}{*}{$P$} \\
\hline & $\bar{x}$ & SE & $\bar{x}$ & $\mathrm{SE}$ & & $\bar{x}$ & SE & $\bar{x}$ & $\mathrm{SE}$ & & & \\
\hline Wood chips $(\mathrm{g})^{\mathrm{a}}$ & 0.0 & 0.0 & 29.5 & 2.2 & $<0.001$ & 0.3 & 0.3 & 15.9 & 2.5 & 1,8 & 13.54 & 0.006 \\
\hline Length $(\mathrm{cm})$ & 0.0 & 0.0 & 22.6 & 5.9 & $<0.001$ & 2.3 & 0.6 & 28.4 & 3.5 & 1,8 & 22.26 & 0.002 \\
\hline Surface area $\left(\mathrm{cm}^{2}\right)$ & 0.0 & 0.0 & 35.7 & 4.4 & $<0.001$ & 1.7 & 0.6 & 29.5 & 3.5 & 1,8 & 39.23 & $<0.001$ \\
\hline Depth $(\mathrm{cm})$ & 0.0 & 0.0 & 0.24 & 0.06 & $<0.001$ & 0.02 & 0.01 & 0.22 & 0.15 & 1,8 & 30.26 & $<0.001$ \\
\hline
\end{tabular}

${ }^{\mathrm{a}}$ Wood chips $(\mathrm{g})=$ wt of wood chips removed $(\mathrm{g})$.

from woodpeckers. An epoxy coating was not successful due to rapid degradation of the epoxy material (Rumsey 1973). The polyurea elastomer material we used did not degrade in the form of chalking or discoloration during 40 days of cage testing and did not degrade after 1 year of environmental testing (Weisner 2008). Environmental longevity of fully coated crossarms is currently being evaluated by Brooks Manufacturing Company; however, the coating should be evaluated under field conditions where crossarms and poles are also subject to regular maintenance by lineman and exposure to other species of woodpeckers.

Marks in the coating may have occurred due to the polyurea elastomer drying out during the 40 days of testing, because we observed more marks during days 20-40 than during days $0-20$. Birds may have been able to scratch the coating with their nails and may have caused some minimal damage when pecking; however, none of these scratches penetrated to the wood. The only damage that penetrated the wood was during the choice test. A male pileated woodpecker in the fully coated treatment group tore a 2.0$\mathrm{cm}$-diameter section of the coating $(1.0 \mathrm{~mm}$ thick) where an air bubble had developed during application of the coating. This tear in the coating revealed bare wood and even though it occurred during the first few days of testing, the woodpecker did not cause further damage.

Although the top-coated application was protective of the portion of the crossarm that it covered, the wood below the treatment was vulnerable to damage. The top-coating also may be less effective in the field, especially for deterring ladder-backed woodpeckers because Dennis (1964) noted that this species frequently inflicts damage to the undersides of utility pole crossarms. Our results showed that although

Table 2. Extent of damage by pileated woodpeckers to fully coated versus top-coated crossarms during a 10-day no-choice test at the National Wildlife Research Center, Fort Collins, Colorado, USA, 15 May 2007 to 14 June 2007.

\begin{tabular}{|c|c|c|c|c|c|}
\hline \multirow[b]{2}{*}{ Type of damage } & \multicolumn{2}{|c|}{ Fully coated } & \multicolumn{2}{|c|}{ Top-coated } & \multirow[b]{2}{*}{$P$} \\
\hline & $\bar{x}$ & $\mathrm{SE}$ & $\bar{x}$ & $\mathrm{SE}$ & \\
\hline Wood chips $(\mathrm{g})^{\mathrm{a}}$ & 0.00 & 0.00 & 1.30 & 0.37 & 0.003 \\
\hline Length $(\mathrm{cm})$ & 0.00 & 0.00 & 4.02 & 1.00 & 0.001 \\
\hline Surface area $\left(\mathrm{cm}^{2}\right)$ & 0.00 & 0.00 & 4.41 & 0.92 & 0.003 \\
\hline Depth $(\mathrm{cm})$ & 0.00 & 0.00 & 0.03 & 0.01 & 0.134 \\
\hline Coating damage $\mathrm{e}^{\mathrm{b}}$ & 0.06 & 0.02 & 0.66 & 0.39 & $N^{c}{ }^{c}$ \\
\hline
\end{tabular}

\footnotetext{
${ }^{\mathrm{a}}$ Wood chips $(\mathrm{g})=$ wt of wood chips removed $(\mathrm{g})$.

${ }^{\mathrm{b}}$ No. of small nicks or scrapes $<2.0 \mathrm{~cm}$.

${ }^{\mathrm{c}} \mathrm{NA}=$ not applicable.
}

woodpeckers in both treatments damaged controls, controls used with the fully coated crossarm sustained more damage than the control used with the top-coated crossarm, which indicates that all crossarms in woodpecker-damaged areas may need to be coated with the polyurea elastomer coating to avoid increased damage to untreated crossarms.

In a survey of decision makers from the public and private sectors of the electricity and distribution-transmission systems, respondents indicated that compared to other materials used in distribution-transmission structures, wood is perceived to be less expensive but has higher maintenance costs than alternative materials. Additionally, it was suggested that manufacturers should focus on improving the durability and maintenance of wood products (Smith et al. 2000). A coating of the polyurea elastomer product would cost approximately $\$ 15$ for a standard crossarm of dimensions $2.4 \mathrm{~m} \times 9.53 \mathrm{~cm} \times 12.07 \mathrm{~cm}$, assuming a 1.78 $\mathrm{mm}$ coating thickness. As a comparison, the cost of a wood crossarm is $\$ 78$ and a fiberglass composite crossarm is $\$ 130$ (Geodata Publishers 2005). Thus, the cost of wood crossarms with protective polyurea elastomer should remain less or comparable to crossarms of other materials (i.e., fiberglass composite) on the market.

\section{Management Implications}

Polyurea-elastomer coating material, especially in the fully coated crossarm application, showed considerable promise for preventing or eliminating damage by woodpeckers. Utility poles often receive more damage and are more expensive to replace than crossarms, thus this coating material also should be evaluated on utility poles. Use of this product could reduce number of visits for maintenance due to damage by pileated woodpeckers, thereby reducing maintenance costs.

\section{Acknowledgments}

Crossarms used for testing were provided by Brooks Manufacturing Company. We thank K. Crooks, C. Ghalambor, G. M. Linz, and S. J. Werner as well as several anonymous reviewers for their thoughtful comments on earlier versions of this manuscript. We thank the staff of NWRC's Animal Care unit for care of the birds throughout the study.

\section{LITERATURE CITED}

Abbey, M., A. Stewart, and J. Morrell. 2000. Existing strategies for control or remediation of woodpecker damage. Internal report: investigation of 
woodpecker damage prevention methods. Reliant Energy, Houston, Texas, USA.

Belant, J. L., T. W. Seamans, R. A. Dolbeer, and P. P. Woronecki. 1997. Evaluation of methyl anthranilate as a woodpecker repellent. International Journal of Pest Management 43:59-62.

Bevanger, K. 1997. Woodpeckers, a nuisance to energy companies. Fauna Norvegica Series C, Cinclus 20:81-92.

Cummings, J. L., R. M. Engeman, P. A. Pochop, D. L. York, and J. E. Davis, Jr. 2001. Evaluation of wire wraps, chemonite treated poles and penta treated laminated poles to reduce pileated woodpecker damage to utility poles. Unpublished research report. United States Department of Agriculture, Animal and Plant Health Inspection Service, Wildlife Services, National Wildlife Research Center QA-768, Fort Collins, Colorado, USA.

Dennis, J. V. 1964. Woodpecker damage to utility poles: with special reference to the role of territory and resonance. Bird-Banding 35:225-253.

Geodata Publishers. 2005. Comparison chart for Amistad's integrated strong arm. <http://www.amistadfiberglass.com/comparisons.html $>$. Accessed 13 Aug 2009.

Jorgensen, R. N., H. T. Pfitzenmeyer, and W. C. Bramble. 1957. Prevention of woodpecker damage to wooden utility poles. Progress Report 173, Pennsylvania State University, State College, USA.
McAtee, W. L. 1911. Woodpeckers in relation to trees and wood products. U.S. Department of Agriculture Biological Survey Bulletin Number 39, Washington, D.C., USA.

Rumsey, R. L. 1970. Woodpecker attack on utility poles. Journal of Forest Products 20:54-59.

Rumsey, R. L. 1973. Woodpecker damage to wooden utility poles. Thesis, Los Angeles State University, Los Angeles, California, USA.

Smith, R. L., W. E. Spradlin, D. R. Alderman, Jr., and E. Cesa. 2000. A perceptional comparison of wood in separate infrastructure markets. Wood and Fiber Science 32:239-255.

Stemmerman, L. A. 1988. Observation of woodpecker damage to electrical distribution line poles in Missouri. Proceedings of the Vertebrate Pest Conference 13:260-265.

Turcek, F. J. 1960. On the damage by birds to power and communication lines. Bird Study 7:231-236.

Weisner, C. 2008. Protective coating for utility pole crossarms (protection from woodpeckers). Proceedings of the international conference on overhead lines. March 2008, EDM International, Inc., Fort Collins, Colorado, USA.

York, D. L., J. E. Davis, Jr., and J. L. Cummings. 1998. Pileated woodpecker capture using a mist net and taped call. North American Bird Bander 23:81-82.

Associate Editor: Mason. 